\title{
Analysis of the Impact of Education on Poverty Reduction and Economic Development in Nigeria
}

\author{
David A. Samuel ${ }^{*} \quad$ Enitan Wale-Odunaiya \\ Department of Economics, Veritas University, Abuja
}

\begin{abstract}
This work investigated the impact of education on poverty reduction and economic development in Nigeria. Data was a time series monthly data between January 2000 and December, 2016. Autoregressive Distributed Lag model was employed for the analysis and the findings revealed that Primary and Secondary school enrolment, Primary school completion rate, Children out of school, literacy rate and government spending on education did not have short run effect on poverty, although they carried the correct signs, but the long run effect was significant. It was therefore recommended among other things, that government spending on education should be more targeted on vocational and practical training that can help the beneficiaries translate to income generation so as to lift them out of poverty.
\end{abstract}

Keywords: Education, Poverty, Economic Development, Government Spending

DOI: $10.7176 / \mathrm{EJBM} / 13-23-03$

Publication date: December $31^{\text {st }} 2021$

\subsection{Introduction}

The contemporary economic studies have shown that the level and quality of knowledge acquisition in a society is a major determinant of economic growth and development in that society. That again goes to imply that no nation can grow to enjoy any tangible development in the absence of comprehensive investment in human capital development Sound education of the citizens, especially those who are poor, reveals the quality of who they really are and the people around them. Their perceptions change and their behavior changes and goes to affect their productivity. Higher quality of education generates improved life's quality and it becomes socially beneficial to the citizens. This self-awareness translates to higher productive capabilities, innovative skills, and gradually builds the entrepreneurial skills which eventually lead to increased technical progress. The end point of all these is to improve the earning potential of the people that are educated and thereby reducing poverty and income inequality tendency It has been confirmed that a good way to increase economic development is to reduce poverty and income inequality (Tabassum and Majeed, 2008;.Lahouij, 2017). Education has been found to increase labour efficiency, thereby improving the productive potential and earning power of the educated, and it becomes the hub around which all social and economic development revolves.

There has been a global upsurge in educational drive and attainment since this century commenced. Education of all genders, adults and children alike has been on the increase. These dimensions of education have spanned both the formal and informal levels, from primary to secondary to tertiary education, from vocational to crafts, artisans and so on. All these levels of learning have improved the acquisition of skills, intellectual or cognitive prowess ability to compete and improved productivity of the educated and the nation at large. Behrman (1990) and Psacharopoulos (1994) discovered that the development of any nation is hinged on the quality of education of the citizens. Quality of education improves earning potentials of individuals whether they live in the rural or urban areas, and secondary and vocational education builds skills necessary for managerial operations. Likewise, in order to build institutions, manage administrations of government parastatals, operate in the judiciary and financial sectors, tertiary education is required and must be attained. It has been revealed that people with a minimum of four years of education were found to be able to practically and technically apply fertilizers and farming inputs more than those who are not in Thailand (Birdsall, 1993).

Quality education results in dual benefits of improving income generation and income inequality reduction. As more and more people gets educated, especially the poor, the more they will have access to earn higher income and the more the opportunities of access to greater opportunities to bridge the inequality gap. It has been discovered that one variable that has the highest level of impact on income inequality is quality of educational attainment (Psacharopoulos, 1994). Similarly, Bourguignon and Morrison (1990) showed that when labour force is increased with the secondary education attainment, it increases the share of income for the 40 percent and 60 percent groups by 6 percent and 15 percent respectively.

Nigeria has one of the largest numbers of schools, from primary to university level, both at public and private ownership. Large chunk of graduates are rolled out on an annual basis, yet without jobs, thereby increasing poverty level. A lot of educational policies have been designed, but the synergy between the education and finance ministries in the implementation has been very weak (Lincove, 2009). Some state governments have embarked on free education in some regions of the country while the federal and state governments began the free feeding programme. But these have not yielded any positive returns on poverty reduction (Fabunmi, 2005). The questions 
to be addressed in this work include: How does the formal educational attainment affect poverty level? In what ways does the expenditure of government on education affect poverty reduction and build development? Which type of education should the country pay more attention to: vocational training and skill acquisition or formal education? Which of the two types of education has more overarching effect on poverty reduction? The following section will examine some of the empirical works done in this area of education and poverty and consequently on development. Section three examines the methodology and model specification and the sources of data. Section four presents the results and analyze it while section five will give the summary and policy recommendations.

\subsection{Literature Review}

The direction of relationship between education and poverty and consequently on a nation's development has been contested in the literature. Filmer and Pritchett (1999) and Pritchett (2001) have argued that the claim of some authors on the degree of effect of quality of training on the growth of GDP has not been as claimed. Temple (2001) argued that education and economic growth are not strongly related on the ground of poor measurement of education. On the other hand, Barro and Lee (2001); Hanushek and Kimko (2000) and Hanushek and Zhang (2006) showed that when education is of high quality, it promotes growth and consequently reduces poverty and improves economic development.

One of the earlier literature showed that investment in primary education brings a high return in terms of the earning potentials than secondary and tertiary education (Psacharopoulos and Patrinos, 2004). However, recent literatures have also shown that investment in secondary and tertiary education yield higher returns in some countries (Murphy and Welch, 1994; Goldin and Katz, 1999).

Hofmarcher (2021) carried out a study that provided evidence of the causal relationship between education, educational level and different dimensions of poverty. The work established that apart from some people falling below the poverty line, some others seem themselves as poor. His work was a construction of a database that was to serve as a reform for education in 32 European countries and they were used as instruments for measuring education. His finding showed that there was a poverty reducing capacity in education. The result showed that any additional year of education reduces the chances of being under the poverty line and of considering oneself as poor.

Alamanda (2020) analyzed with the method of Panel regression based on 33 provinces in Indonesia the effect of spending of government on education on poverty reduction between 2005 and 2017. It was found that expenditure like social aids, grants and subsidy do not have any significant effect on poverty. However, the spending on infrastructure was found to be negatively related to inequality and poverty both in the urban and rural areas, but it was observed that the impact is stronger in the rural than urban areas.

Efendi and Indartono (2019) carried out an analysis of the links between poverty, economic growth, health and education in Indonesia between 2004 and 2017. Secondary data and Ordinary Least Squares estimation technique was used and the findings indicated that poverty and economic growth are positively but not significant relationship and it was also found that education had a negative and insignificant relationship with poverty in the country. The finding further showed that education, health and economic growth explained poverty at about 88 percent from the R square statistic. Education and poverty further confirmed the theoretical postulations on the relationship between them in Indonesia.

Mahmut, Omar and Yunus (2019) examined the effect and relationship between government expenditure on health and education on poverty and to check how economic growth affects poverty and to determine the direction of causality among the variables in eight Central and Eastern European countries in 2005 and 2016. The work employed a Panel regression and the findings revealed that there was a negative relationship between health and education expenditure and poverty and between economic growth and poverty as well. It was also established that there was a one way causality running from expenditure on health and education to poverty but there was a twoway causality from economic growth to poverty. The recommendation therefore was to budget more funding for education to boost earnings of the citizens and reduce poverty.

Edeh, Obi and Obi (2018) examined the effect of government education spending on poverty reduction in Nigeria for the period 1999 to 2017. Time series data on primary school enrolment and government expenditure on education were used to capture education variable and the work employed the Ordinary Least Square analysis. The findings showed that government spending on education did not affect poverty significantly. It was therefore recommended that policies that can translate to poverty reduction such as vocational training should be encouraged to make more impact on poverty reduction.

Machmud and Ahman (2017) conducted an analysis on how education affects poverty in Indonesia between 2004 and 2015. The work employed a secondary data and Ordinary Least Squares estimation method and it was revealed that education and poverty exhibited very strong and negative relationship in the country. This result shows that when education is improved poverty can be reduced.

Ukwueze and Nwosu (2014) studied the effect of higher education on poverty level in Nigeria 2004 using National Living Standard Survey. The work employed the methodology of propensity score matching and Logistic regression and it was found that higher education has the potential of reducing poverty in the country. It was 
therefore recommended that annual project of government should include higher education expenditure especially in adapting international benchmark on education funding.

Ehigiamusoe (2013) examined the interrelationship among education, economic growth and poverty in Nigeria between 1980 and 2012. The work employed Vector Error Correction Mechanism estimation technique and it was found that despite the long run relationship among the variables, expenditure on education and economic growth could not significantly affect poverty in the country. It was therefore recommended that government should increase budgetary allocation to education sector and there should be a change in the curricula of education to tailor it towards growth enhancing training and educational standards.

Maiyo and Jyoti (2011) investigated the relationship between education measured via literacy rate, enrolment rate and dropout rate and poverty measured via poverty headcount in some regions in Kenya. Employing a descriptive analysis, it was found that regions with high literacy rate, enrolment rate and low dropout rate experienced low poverty while regions with low literacy rate, low enrolment rate and high dropout rate experienced high poverty rate. The study recommended the introduction of programmes that can allow the poor and very poor to have the opportunity to enroll and get educated to lift them out of the poverty level.

Awan, Malik, Sarwar and Waqas (2011) carried out an evaluation of the effect of different levels of education on poverty in Pakistan between 1998 and 2001, using Logistic regression method. The findings showed that educational attainment and experience had a negative relationship with poverty in that period under study. It was also revealed from the result that people with higher education are less likely to be poor. It was also discovered that educated male have the opportunity to have access to jobs that is above poverty level.

Afzal, Ehsan, Ishrat, Kafeel and Hina (2008) conducted a study on Pakistan between 1971 and 2009 using time series data and with the methodology of Autoregressive Distributed Lag Model (ARDL) to find out the relationship between education and poverty and economic growth. It was revealed from the findings that education affects economic growth positively in the long run while it was discovered that poverty and economic growth are negatively related. It was therefore revealed that education and poverty are inversely related. Granger causality revealed that education and growth, growth and poverty, education and poverty can Granger cause each other. It was therefore recommended that policies that can enhance education and reduce poverty should be designed to accelerate growth in the country.

\subsection{Theoretical Framework}

Becker (1975) provided a theory of human capital on which this work is hinged. This theory linked the possibility of controlling poverty on the earning potential of an individual. This is explained by the preference of an individual to invest in education as a result of the expected returns from the investment in that education or human capital development. People that expect more from their expenditure in education tend to spend more money and time to train because they believe that they will be compensated at the end of the day. This can be summed as the motivation to invest is determined by the expected return from investment in education. Every expenditure in education comes with two cost implications. Firstly, the payment for the training itself, which is called direct cost and the second is the cost of foregone earnings while in training, which can be referred to as opportunity. Consequent upon the cost and the expectation of returns, people that anticipate that they might not have the privilege to enjoy the returns of investing in education may be reluctant to invest, people like the women and the very poor in the society. This will further perpetuate the poverty tendency among these categories of people.

It can be deduced from this theory that investment in education and poverty reduction are related to a large extent. Reduction in poverty on the other hand enhances economic development in a country. This theoretical underpinning presents a structure of how to attain the human development indices like investment in knowledge, living long and living healthy and attaining higher living standard. The transmission mechanism is from high quality education to more earnings to better healthy living and long life and higher standard of living.

\subsection{Methodology}

This work will be employing an econometric analytical method adapted from the work of Ehigiamusoe (2013) and Machmud and Ahman (2017) who used expenditure on education and economic growth and education as independent variable respectively to explain poverty level in Nigeria between 1980 and 2012. This study will be employing the following variable as independent variables (Primary School Enrolment, Secondary School Enrolment, Childrn Out of School, Primary Completion rate, Literacy Level, Government expenditure on education and Poverty rate. The relationship can be functionally expressed as:

$$
P O R=f(P S E, S S E, C O O S, P C R, \text { LITR, GEE }) \quad \ldots
$$

Equation 3.1 can be re-expressed econometrically as:

$$
P O R_{t}=\alpha_{0}+\beta_{1} P S E_{t}+\beta_{2} S S E_{t}+\beta_{3} \text { COOS }_{t}+\beta_{4} P C R_{t}+\beta_{5} L_{T T R}+\beta_{6} G E E_{t}+\mu_{t}
$$

Where: POR $=$ Poverty Rate, PSE $=$ Primary School Enrolment, SSE $=$ Secondary School Enrolment, COOS $=$ Children out of School, PCR $=$ Primary Completion rate, LITR $=$ Literacy Rate, GEE $=$ Government Expenditure on Education, $\mu_{t}=$ Error term that satisfies the assumptions of OLS, $\alpha_{0}=$ Intercept constant, $\beta_{i}=$ Parameter 
coefficients to be estimated.

A Priori Expectation

$\beta_{1}<0, \beta_{2}<0, \beta_{3}>0, \beta_{4}<0, \beta_{5}<0, \beta_{6}<0$

\subsection{Data and Sources}

The data for this work is a time series monthly secondary data between January 2000 and December 2016. The choice of this start and ending date is due to availability of data. Poverty rate, Primary School Enrolment, Secondary School Enrolment, Children out of school, Primary School completion rate are all sourced from World Development Indicator of the World Bank data base, while Literacy rate, Government expenditure on education were sourced from the data bank of National Bureau of Statistics.

\subsection{Specification of ARDL Model}

The unit root test was carried out and the results showed that the variables were integrated at both 1 and 0 , that is, I(1) and I(0). Consequently, this work employed the Autoregressive Distributed Lag (ARDL) Bounds Test to check for cointegration and if found, we estimated the long run model with Error Correction Model.

The generalized ARDL (p, q) model is specified as below:

$$
Y_{t}=\alpha_{0 j}+\sum_{i=1}^{p} \partial_{j} Y_{t-1}+\sum_{i=0}^{q} \beta_{j} X_{t-1}+\varepsilon_{j t}
$$

The steps to estimate the ECM were as follows:

i. $\quad$ Establish the cointegration using Bounds testing

ii. If there is cointegration, choose appropriate optimal lag length.

iii. Estimation of the long run ARDL model

iv. Reparameterization of ARDL model into Error Correction Model

For an ARDL of this order ( $\left.p, q 1, q 2, q 3, q 4, q 5, q^{6}, q^{7}\right)$

The long run relationship for this work is also expressed as follows:

$P O R_{t}=a_{01}+b_{11}$ POR $_{t-1}+b_{21}$ PSE $_{t-1}+b_{31} S S E_{t-1}+b_{41}$ COOS $_{t-1}+b_{51}$ PCR $_{t-1}+b_{61} L_{I T R_{t-1}}+b_{71} G E E_{t-1}+$ $e_{1 t}$

When there is cointegration, the Error Correction Model (ECM) is then specified as follows:

$\triangle P O R_{t}=\mathrm{a}_{0}+\quad \sum_{i=1}^{p} a_{1 j} \Delta P O R_{t-1}+\sum_{i=1}^{q 1} a_{2 j} \Delta P S E_{t-1}+\sum_{i=1}^{q 2} a_{3 j} \Delta S S E_{t-1}+\sum_{i=1}^{p 3} a_{4 j} \Delta C O O S_{t-1}+$ $\sum_{i=1}^{p 4} a_{5 j} \Delta P C R_{t-1}+\sum_{i=1}^{p 5} a_{6 j} \Delta L I T R_{t-1}+\sum_{i=1}^{p 6} a_{7 j} \Delta G E E_{t-1}+\gamma E C T_{t-1}+e_{t}$

The Error Correction Model (ECM) can be derived from ARDL model through a simple linear transformation, which integrates short run adjustments with long run equilibrium without losing long run information.

\subsection{Presentation and Analysis of Results}

\subsection{Unit Root test result}

The stationary condition of the variables were tested using Augmented Dickey Fuller test method and it was found that there was a mixture of integration at 0 and 1 or $\mathrm{I}(0)$ and $\mathrm{I}(1)$ as presented in table 4.1. This test result suggested that the estimation method to be used is Autoregressive Distributed Lag (ARDL) model and using the Bounds testing for cointegration method.

Table 4.1: Unit Root test result

\begin{tabular}{|c|c|c|c|c|c|c|c|}
\hline & At Level & & & At First I & rence & & \\
\hline Variable & ADF Stat & $5 \%$ Level & $\begin{array}{l}\text { Prob. } \\
\text { Value }\end{array}$ & ADF Stat & $5 \%$ Level & $\begin{array}{l}\text { Prob. } \\
\text { Value }\end{array}$ & $\begin{array}{l}\text { Order of } \\
\text { Integration }\end{array}$ \\
\hline POR & -1.1776 & -2.87668 & 0.6840 & -2.7795 & -2.87668 & 0.0331 & $\mathrm{I}(1)$ \\
\hline PSE & 1.905255 & -2.87764 & 0.9998 & -4.32487 & -2.87773 & 0.0014 & $\mathrm{I}(1)$ \\
\hline SSE & -1.77184 & -2.87668 & 0.3936 & -3.4817 & -2.87668 & 0.0095 & $\mathrm{I}(1)$ \\
\hline PCR & -1.26319 & -2.87668 & 0.6464 & -3.16144 & -2.87668 & 0.0239 & $\mathrm{I}(1)$ \\
\hline LNGEE & -1.89005 & -2.87583 & 0.3366 & -4.10289 & -2.87583 & 0.0012 & $\mathrm{I}(1)$ \\
\hline COOS & -5.65866 & -2.87575 & 0.0000 & & & & $\mathrm{I}(0)$ \\
\hline LITR & -3.8975 & -2.87583 & 0.0025 & & & & $\mathrm{I}(0)$ \\
\hline
\end{tabular}

Source: Author computed using Eviews 10

\subsection{Cointegration test result}

As a result of the unit root test, this work adopts the Bounds testing under Autoregressive Distributed Lag model to check if there is a long run relationship among the variables. The result is presented in table 4.2. Bounds test uses the F-test against the levels of integration. The null hypothesis is that there is no cointegration. The dicision rules are: If the F-statistic is lower than the lower bound value $\mathrm{I}(0)$ at the significant level of interest, we accept that there is no cointegration. But if the F-statistic lies between the lower bound and upper bound values, it is 
undecided. On the other hand, if the F-statistic is greater than the upper bound values, we reject the null hypothesis and conclude that there is cointegration. From table 4.2, F-statistic (7.456) is greater than the upper bound value at 5 percent level of significance, and we therefore conclude that there is cointegration among the variables. The implication of this is that the variables have a long run relationship together.

Table 4.2: Cointegration test result

\begin{tabular}{|l|l|l|l|l|}
\hline \multicolumn{5}{|l|}{ F-Bounds Test } \\
\hline Null Hypothesis: No Cointegration & \multicolumn{1}{l|}{} \\
\hline Test Statistic & Value & Significant. Level & $\mathrm{I}(0)$ & $\mathrm{I}(1)$ \\
\hline F-statistic & 7.455947 & $10 \%$ & 1.99 & 2.94 \\
\hline & & $5 \%$ & 2.27 & 3.28 \\
\hline & & $2.5 \%$ & 2.55 & 3.61 \\
\hline & & $1 \%$ & 2.88 & 3.99 \\
\hline
\end{tabular}

Source: Author computed using Eviews 10

\subsection{Error Correction Mechanism}

In order to estimate the Error Correction Model (ECM), we had to estimate the long run model and extracted the residual and then renamed it ECT which became a variable to be estimated in the ECM. The ECT is the long run representation in the ECM, which is a combination of short run and long run representation. ECM is presented in table 4.3 and it showed the short run and long relationships among the variables.

Table 4.3: Error Correction Mechanism

\begin{tabular}{|l|l|l|l|l|}
\hline Dependent Variable: D(POR) & Coefficient & Std. Error & t-Statistic & Prob. \\
\hline Variable & 0.011521 & 0.062952 & 0.183013 & 0.855 \\
\hline C & 1.091296 & 0.211014 & 5.171678 & 0.0000 \\
\hline D(POR(-1)) & 1.286941 & 1.167929 & 1.101901 & 0.272 \\
\hline D(PSE(-1)) & -1.23924 & 1.230044 & -1.00747 & 0.3151 \\
\hline D(PSE(-2)) & 0.179095 & 0.110863 & 1.61546 & 0.108 \\
\hline D(SSE(-1)) & -0.08687 & 0.113357 & -0.76637 & 0.4445 \\
\hline D(LNCOOS(-1)) & $9.46 \mathrm{E}+01$ & $8.14 \mathrm{E}+01$ & 1.162395 & 0.2466 \\
\hline D(LNCOOS(-2)) & $-1.11 \mathrm{E}+02$ & $7.46 \mathrm{E}+01$ & -1.48308 & 0.1398 \\
\hline D(PCR(-1)) & 0.421201 & 0.268699 & 1.567555 & 0.1188 \\
\hline D(PCR(-2)) & -0.27001 & 0.244713 & -1.10335 & 0.2714 \\
\hline D(LITR(-1)) & -3.7752 & 3.342866 & -1.12933 & 0.2603 \\
\hline D(LITR(-2)) & 4.168731 & 3.199621 & 1.302883 & 0.1943 \\
\hline D(LNGEE(-1)) & $-4.90 \mathrm{E}+00$ & $3.27 \mathrm{E}+00$ & -1.49992 & 0.1354 \\
\hline D(LNGEE(-2)) & $4.62 \mathrm{E}+00$ & $2.88 \mathrm{E}+00$ & 1.604582 & 0.1104 \\
\hline ECT(-1) & -0.76272 & 0.23871 & -3.19515 & 0.0017 \\
\hline R-squared & 0.450698 & & & \\
\hline Adjusted R-squared & 0.407003 & & & \\
\hline F-statistic & 10.31474 & & & \\
\hline Prob(F-statistic) & 0.0000 & & & \\
\hline Durbin-Watson stat & & 2.062296 & & \\
\hline Source: Author computed & & & \\
\hline
\end{tabular}

Source: Author computed using Eviews 10

From table 4.3, poverty rate in the previous period affect current poverty rate positively. It could be observed that 1 percent increase in poverty in the last period would lead to 109 percent increase in current poverty rate. It was also observed that poverty rate in the previous period significantly affects poverty in current period.

Primary school enrolment rate in the previous period carried a wrong sign, but the previous two periods carried the correct sign (-1.23924), but not significant. This result showed that 1 percent increase in primary school enrolment rate will reduce poverty by 123 percent. Secondary school enrolment rate in the previous period also carried a wrong sign but the previous two periods carried the correct sign $(-0.08687)$. This showed that 1 percent increase secondary enrolment rate decreases poverty by 8.7 percent. That implies primary school enrolment has more impact on poverty than secondary school enrolment rate.

Children out of school in the previous period carried the right sign but carried the wrong sign in the previous two periods. The result showed that as children out of school decreases, poverty also declines. On the other hand, primary school completion rate in the previous carried a wrong sign but carried the right sign $(-0.27001)$ in the previous two periods. This result suggested that 1 percent increase in the completion rate will lead to 27 percent in poverty rate.

Literacy rate in the previous period carried the correct sign $(-3.7752)$ but not significant, but the previous two 
periods did not carry the correct sign. The result of the previous period indicated that 1 percent increase in literacy rate leads to about 378 percent reduction in poverty. This revealed how important education is to poverty reduction. It showed that education is a major channel to reduce poverty, howbeit, not significant.

Government spending on education in the previous period carried the correct sign $(-4.90 \mathrm{E}+00)$ or -4.9 and it showed that as government expenditure increases, poverty rate reduces, or 1 percent increase in government expenditure reduces poverty by 4.9 percent, howbeit, not significant.

The Error Correction Term coefficient (-0.76272) is rightly signed and significant at p-value of 0.01 percent. The coefficient showed the speed of adjustment to long run equilibrium, which is 76 percent per month. This showed that the variables are strongly related and the independent variables affect the dependent variable in the long run.

\subsection{Residual Diagnostic tests}

In order for the model to have a policy and forecast benefit, the assumptions underlying the OLS must be satisfied. They are assumptions of no serial correlation, homoskedasticity and normality. The results of the tests are in table 4.4. The decision rule is that if the p-values are greater than 5 percent significant level, then the assumptions are satisfied.

Table 4.4: Residual diagnostic test results

\begin{tabular}{|l|l|}
\hline Residual Diagnostic test & 0.1461 \\
\hline Breusch-Godfrey Serial Correlation LM Test & 0.826 \\
\hline Heteroskedasticity Test: Breusch-Pagan-Godfrey & 0.0000 \\
\hline Normality test: Jarque-Bera & \\
\hline
\end{tabular}

Source: Author computed using Eviews 10

The serial correlation and heteroscedasticity tests showed that the assumptions are satisfied, the Jarque-Bera test showed that the residuals are not normally distributed with a p-value less than 5 percent significant level. The absence of serial correlation showed that the model is good for forecast and policy purposes.

\subsection{Stability test result}

Stability test is to display how the parameters are stable over time. The test is conducted by CUSUM test as shown in figure 4.1.

\section{Figure 4.1: Stability test}

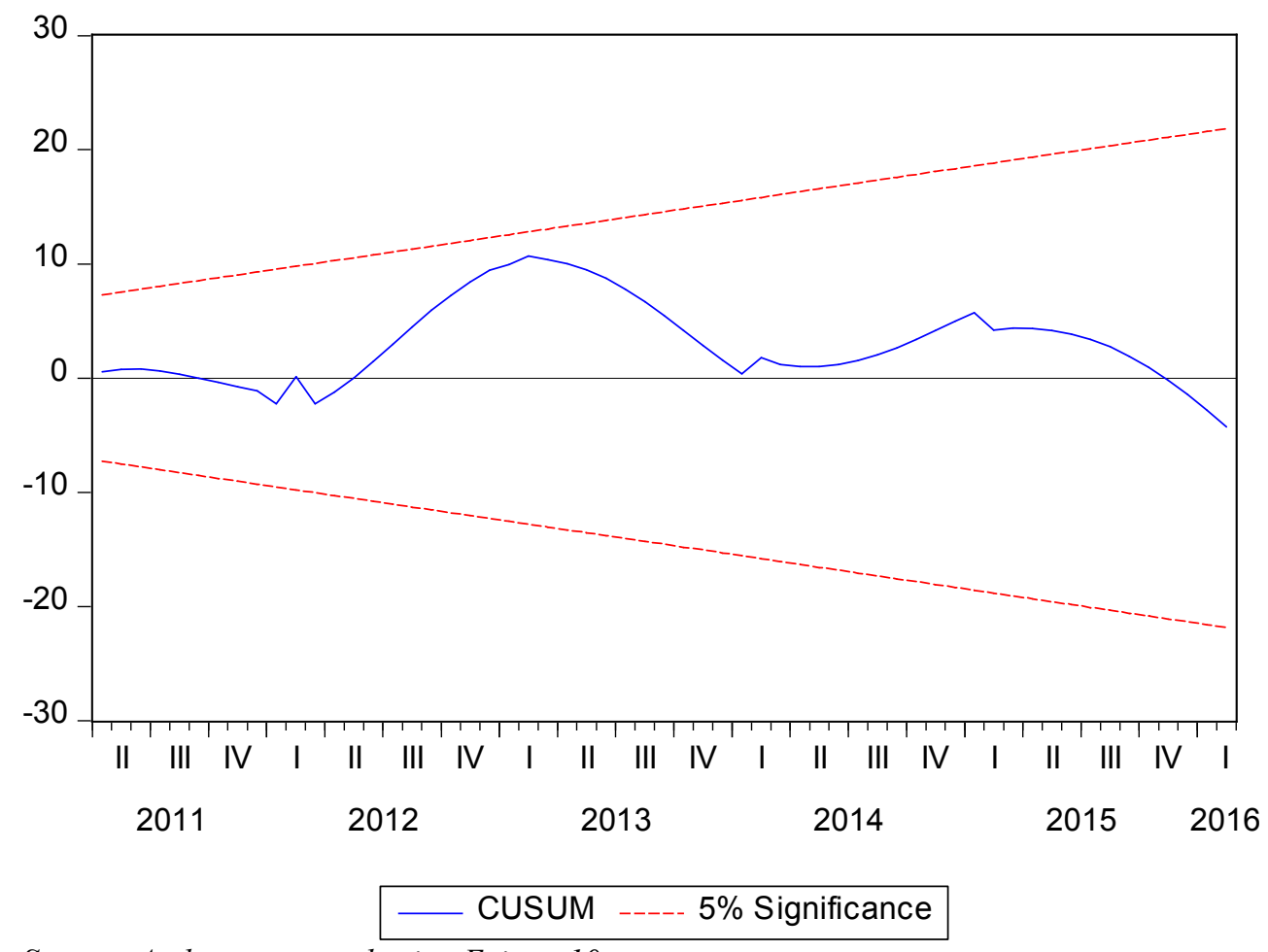

Source: Author generated using Eviews 10

The decision rule is that if the model lies in between the 5 percent level of significance, then the model parameters are stable. Figure 4.1 showed that the parameters are stable. Figure 4.2 showed the CUSUM square test which showed that even when the regression is changed or subject to shocks, the parameters are stable over 
time.

Figure 4.2: CUSUM OF SQUARES

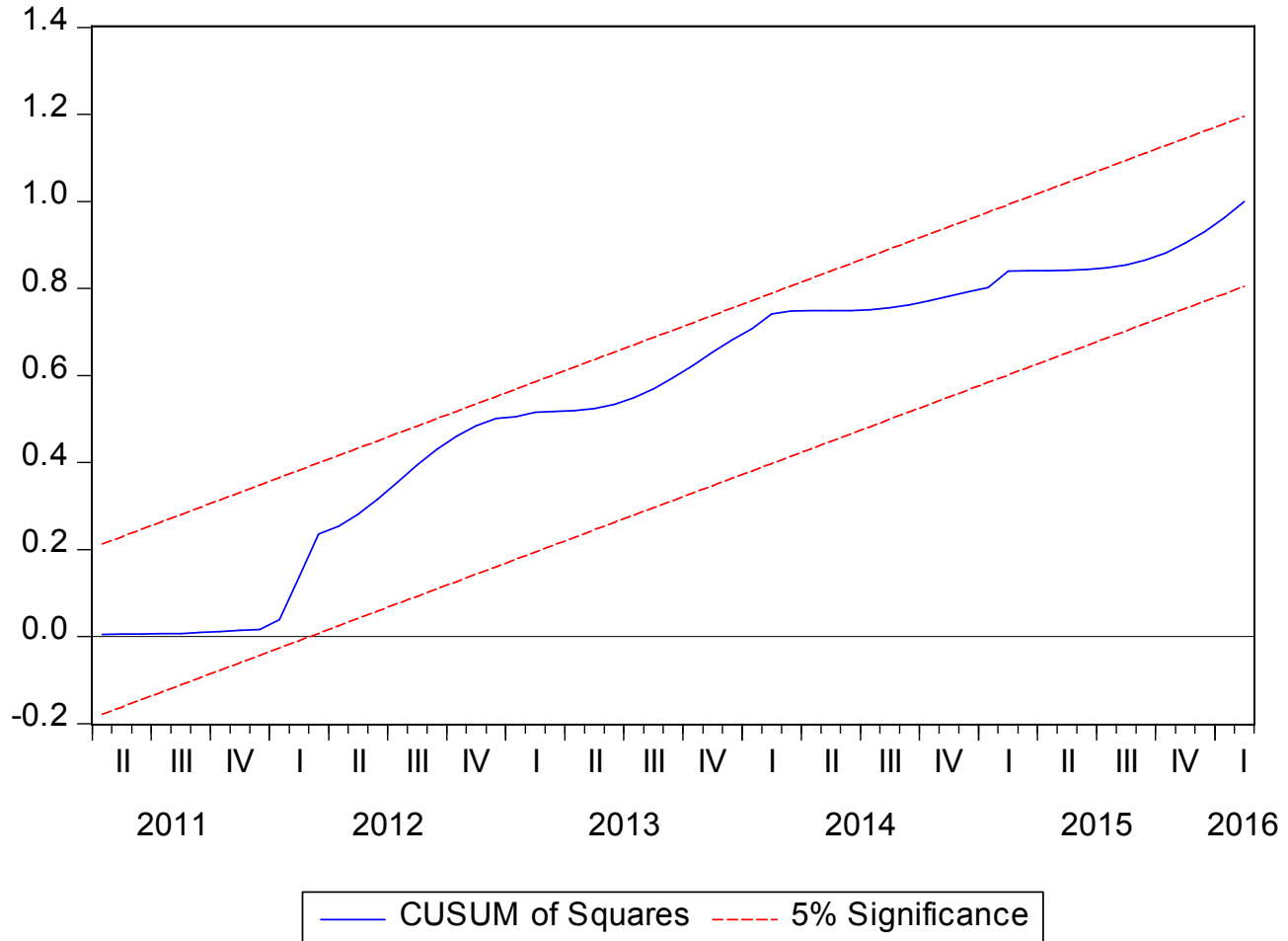

Source: Author generated using Eviews 10

\subsection{Conclusion and Policy Recommendations}

This work had investigated the effect of education on poverty and economic development. It was found that different measures of education had different effect on poverty rate in Nigeria. It was also found that none of the measures of education affect poverty in the short run but all have a strong effect on poverty in the long run. Enrolment rate both at primary and secondary schools, completion rate, literacy rate, children out of school and government expenditure on education all have long run effect on poverty in Nigeria.

On the ground of the findings it is therefore recommended that:

i. Policies that can make more children enroll both at primary and secondary school level should be designed, preferably, free education policies and incentives to parents to ensure their children go to enroll.

ii. It is imperative that policies that will keep the children in school such as increased scholarships, and assurance of job after leaving school should be made available.

iii. Government spending to boost education, especially vocational and practical training programmes should be increased. Emphasis on formal education should be reduced or should be at par with the emphasis on vocational training.

\section{References}

Afzal, M., Ehsan, M.M., Ishrat, B., Kafeel and Hina, F. (2008). Relationship among Education, Poverty and Economic Growth in Pakistan: An Econometric Analysis. Journal of Elementary Education, 22(1), $23-45$.

Alamanda, A. (2020). The Effect of Government Expenditure on Income Inequality and Poverty in Indonesia. 4(1), $1-11$.

Awan, M. S., Malik, N., Sarwar, H. and Waqas, M. (2011). Impact of Education on Poverty reduction. MPRA Paper 31826, University Library of Munich, Germany.

Barro, R., and Lee, J.W. (2001). Schooling quality in a crosssection of countries. Economica, 68(272), 465-488

Behrman, Jere R. (1990), Human Resource Led Development, Review of Issues and Development, New Delhi, India: ARTEP/ILO.

Birdsall, N. (1993), "Social Development in Economic Development", World Bank Policy research working Papers, WPS 1123, Washington DC.

Bourguignon, F. and C. Morrison (1990), "Income Distribution, Development and Foreign Trade: A Crosssectional Analysis", European Economic Review, 34.

Edeh, C.E., Obi, A. and Obi, C. O. (2018). Impact of Education Spending on Poverty Reduction in a Democratic Dispensation in Nigeria. International Journal of Economics and Financial Management. 3(3), 1-9. 
Efendi, R. and Indartono, S. (2019). The Relationship of Indonesia's Poverty Rate Based on Economic Growth, Health, and Education. International Journal of Multicultural and Multireligious Understanding (IJMMU), $6(2), 323-330$.

Ehigiamusoe, U. K. (2013). Education, Economic Growth \& Poverty Rate in Nigeria: Any Nexus? Journal of Social and Development Sciences, 4(12), 544-553.

Fabunmi, M. (2005). Historical Analysis Of Educational Policy Formulation In Nigeria: ImplicationsFor Educational Planning And Policy. International Journal of African \& African American Studies, 4(2), 1-7.

Filmer, D., and Pritchett, L. (1999). The effect of household wealth on educational attainment: Evidence from 35 countries. Population and Development Review, 25(1), 85-120.

Goldin, C., and Katz, L. F. (1999). The returns to skills in the United States across the twentieth century. NBER Working Paper 7126. Cambridge, Mass.: National Bureau of Economic Research.

Hanushek, E., and Kimko, D.D. (2000). Schooling, labor force quality and the growth of nations. American Economic Review, 90(5), 1184-1208.

Hanushek, E. A., and Zhang, L. (2006). Quality-consistent estimates of international returns to skills.NBER Working Paper 12664. Cambridge, Mass.: National Bureau of Economic Research.

Hofmarcher, T. (2021). The effect of education on poverty: A European perspective. Economics ofEducation Review, 83, https://www.sciencedirect.com/science/article/abs/pii/S0272775721000431

Lahouij, H. (2017). The Effects of Income inequality on Economic Growth Evidence from MENA Countries. Awards for Excellence in Student Research and Creative Activity-Documents. 4.

Lincove, J. (2009). Determinants of schooling for boys and girls in Nigeria under a policy of free primary education. Economics of Education Review, 28(4), 474-484.

Machmud, A. and Ahman, E. (2017). Relationship Education with Poverty in Indonesia. Proceedings of the 2nd International Conference on Economic Education and Entrepreneurship (ICEEE 2017), 74-77.

Mahmut, U. S., Omar, F. O. and Yunus, E. Y. (2019). The Effect of Health and Education Expenditures on Poverty: The Case of Central and Eastern European Countries. The Circular Economy and Its Implications on Sustainability and the Green Supply Chain, pp. 21. https://www.igi-global.com/chapter/the-effect-of- healthand-education- expenditures-on-poverty/220292.

Maiyo, K. J. and Jyoti, B. (2011). Education And Poverty, Relationship And Concerns. A Case For Kenya. Problems of Education in the 21st century Volume 32, 2011.

Murphy, K. M., and Welch, F. (1994). Industrial change and the rising importance of skills. In S. Danziger, \& P. Gottschalk (Eds.), Uneven tides: Rising inequality in America. (pp. 101-132). New York: ussel Sage Foundation.

Ukwueze, E.R and Nwosu, E. O. (2014). Does Higher Education Reduce Poverty Among Youths in Nigeria? Asian Economic and Financial Review, 4(1):1-19.

Pritchett, L. (2001). Where has all the education gone? World Bank Economic Review, 15(3), 367-391.

Psacharopoulos, G. (1994), "Returns to Investment in Education: Aglobal Update", World Development, 22(9).

Psacharopoulos, G., and Patrinos, H. (2004). Returns to investment in education: a further update. Education Economics, 12(2), 111-134.

Tabassum, A. and Majeed, M. T. (2008). Economic Growth and Income Inequality Relationship: Role of Credit Market Imperfection. Pakistan Development Review 47 (4), 727-743.

Temple, J. (2001). Generalizations that aren't? Evidence on education and growth. European Economic Review, $45,905-919$. 